\title{
Perforated gastric carcinoma: a report of 10 cases and review of the literature
}

\author{
Franco Roviello*1, Simone Rossi ${ }^{1}$, Daniele Marrelli ${ }^{1}$, Giovanni De Manzoni², \\ Corrado Pedrazzani ${ }^{2}$, Paolo Morgagni ${ }^{3}$, Giovanni Corso ${ }^{1}$ and Enrico Pinto ${ }^{1}$
}

\begin{abstract}
Address: ${ }^{1}$ Dipartimento di Chirurgia Generale ed Oncologica, University of Siena, Italy, ${ }^{2}$ Istituto di Semeiotica Chirurgica, University of Verona, Italy and ${ }^{3}$ Divisione di Chirurgia 1, G.B. Morgagni Hospital, Forlì, Italy

Email: Franco Roviello* - roviello@unisi.it; Simone Rossi - rossidelmonte@gmail.com; Daniele Marrelli - marrelli@unisi.it; Giovanni De Manzoni - nadaffona@interfree.it; Corrado Pedrazzani - corra@hotmail.com; Paolo Morgagni - pmorgagn@ausl.fo.it; Giovanni Corso - corso5@unisi.it; Enrico Pinto - pinto@unisi.it

* Corresponding author
\end{abstract}

Published: 30 March 2006

World Journal of Surgical Oncology 2006, 4:19 doi:10.1186/1477-7819-4-19

This article is available from: http://www.wjso.com/content/4/I/I9

(C) 2006 Roviello et al; licensee BioMed Central Ltd.

This is an Open Access article distributed under the terms of the Creative Commons Attribution License (http://creativecommons.org/licenses/by/2.0), which permits unrestricted use, distribution, and reproduction in any medium, provided the original work is properly cited.
Received: 07 October 2005

Accepted: 30 March 2006

\begin{abstract}
Background: Perforation is a rare complication of gastric carcinoma, accounting for less than $1 \%$ of all gastric cancer cases. The aim of the present study is to evaluate the prognostic value of perforation and to point out the surgical treatment options.

Methods: A total of 10 patients with perforated gastric carcinoma were retrospectively reviewed among 2564 consecutive cases of gastric cancer operated in three Centers belonging to the Italian Research Group for Gastric Cancer. The clinicopathological features including tumor stage and survival were analyzed and compared to literature data.

Results: Incidence rate was $0.39 \%$. All patients underwent emergency surgery, being performed gastrectomy in 6 patients (mortality 17\%) and repair surgery in 4 patients (mortality 75\%). The survival of patients was related to the stage of the disease, with 2 long-survival cases.

Conclusion: Perforation usually occurs in advanced stages of gastric cancer; nevertheless surgeons should not be always discouraged from a radical treatment of perforated gastric cancer, since perforation even occurs in early stages and seems not to be a negative prognostic factor itself. When possible, emergency gastrectomy should be performed, leaving repair surgery for unresectable tumors. A two-stage treatment is a good treatment option for frail patients with resectable tumors.
\end{abstract}

\section{Background}

Perforation of gastric carcinoma results in an acute abdominal syndrome due to the spilled gastric contents and the consequent peritonitis. It is a rare condition representing less than $1 \%$ of gastric cancer cases in the reports of the last years $[1,2]$ and up to $6 \%$ in reports dated before 1980 [3-5]; it has been reported that about $10-16 \%$ of all gastric perforations are caused by gastric carcinoma [6-9]. In most instances gastric carcinoma is not suspected as the cause of perforation prior to emergency laparotomy and the diagnosis of malignancy is often made only on postoperative pathologic examination. It is often difficult to recognize the kind of lesion that caused gastric perforation at the time of emergency surgery, particularly when 
Table I: Clinicopathological features of patients with perforated gastric cancer.

\begin{tabular}{ll}
\hline \multicolumn{1}{c}{ Variable } & Number of Patients \\
\hline Age & \\
Range (yr)/Mean & $50-82 / 68$ \\
Sex & $6 / 10$ \\
Male & $4 / 10$ \\
Female & \\
Preoperative diagnosis & $10 / 10$ \\
$\quad$ Perforation & $3 / 10$ \\
Cancer & \\
Location & $8 / 10$ \\
Lower third & $1 / 10$ \\
Middle third & $1 / 10$ \\
Upper third & \\
Serosal invasion* & $4 / 6$ \\
Absent & $2 / 6$ \\
Present & $1 / 5$ \\
Lauren histological type* & $4 / 5$ \\
Diffuse & \\
Intestinal & $4 / 6$ \\
Lymph node metastasis* & \\
Absent & \\
Present & \\
Stage of disease & \\
I & \\
II & \\
III & \\
IV & \\
Surgery & \\
Gastrectomy & \\
Local repair & \\
Lymph node dissection & \\
Extended (D2, D3) & \\
Limited (D0, DI) & \\
\hline & \\
\hline
\end{tabular}

*data not available for all patients.

pathologic evaluation of frozen sections is not available. The treatment should aim to manage both the emergency condition of peritonitis and the oncologic technical aspects of surgery: it may be hazardous to embark on a major procedure observing the principles of radical oncological surgery; on the other hand a limited procedure only may jeopardize long-term survival in a patient with potentially curable gastric malignancy. In order to further understand the optimal management of patients with perforated gastric cancer, we reviewed the clinicopathological features and surgical results in our experience, comparing data with the International literature.

\section{Methods}

We reviewed the medical records of 2564 patients with gastric cancer who had undergone surgical treatment in three Centers belonging to the Italian Research Group for Gastric Cancer (IRGGC): Dipartimento di Chirurgia Generale ed Oncologica, University of Siena, Istituto di Semeiotica Chirurgica, University of Verona and Divisione di
Chirurgia 1, G.B. Morgagni Hospital, Forlì. Ten patients $(0.39 \%)$ were treated for perforated gastric carcinoma. The clinicopathological features of all patients were analyzed on the basis of their medical records. Age and sex, preoperative diagnosis, location of perforation, depth of gastric wall invasion, absence or presence of lymph node metastasis, type of surgery, degree of lymph node dissection, UICC stage and outcome of the patients were examined. Overall survival from the time of primary operation was calculated using Kaplan-Meier estimates. A search of the literature was conducted in the Medline database; the terms "perforated", "perforation", "gastric cancer", "gastric ulcer" were associated for the search and English language journals only were selected.

\section{Results}

Clinicopathological features of patients are given in Table 1 . The incidence rate of perforation among gastric carcinoma was $0.39 \%$. Most cases were tumors invading serosa $(4 / 6)$ and with metastatic lymph nodes $(4 / 6)$. The disease was more frequently in stages III/IV (7/10), but one case $(1 / 10)$ of stage I gastric cancer was also observed. All patients underwent emergency surgery. In only 3 patients on 10 a preoperative diagnosis of gastric carcinoma was made. Table 2 shows surgical and postsurgical survival data. Operations performed were gastrectomy in 6 patients and simple closure in 4 patients. Surgery-related deaths were observed in 4 patients: 3 of them underwent simple closure and 1 subtotal gastrectomy. All tumors treated with simple closure were at clinical stage IV of the disease and emergency gastrectomy was not performed because of the advanced stage with adjacent organs invasion. Five subtotal gastrectomies (4 D1 and 1 D2) and one D3 total gastrectomy were performed. Three surgical and two non-surgical complications were observed. The only patient who survived surgery after simple repair died at 5.2 months from operation for the primary disease. The only patient who underwent gastrectomy whose death was surgery-related was 80 and presented cardiologic comorbidity. Two patients underwent adjuvant chemotherapy and they both are still alive after 47.7 and 41.6 months after surgery, one with no evidence of disease and the other with bone recurrence.

\section{Discussion}

Perforation is a rare complication of gastric cancer. In our series an incidence of less than $1 \%(0.39 \%)$ was observed comparable to the most recent studies[1,2]. Preoperative diagnosis of malignancy is unusual, accounting for about $30 \%$ of cases $[1,2,10]$; the other patients are usually accepted for acute abdomen at the Emergency Units where generic preoperative diagnosis of gastroduodenal perforation is made. The only preoperative feature that may guide the surgeon is the age of the patient: perforated gastric carcinoma usually occurs in patients with a mean 
Table 2: Postsurgical survival data for patients with perforated gastric carcinoma.

\begin{tabular}{cccccccccc}
\hline Case Sex & Age & TNM & Stage & Type of surgery Comorbidities & $\begin{array}{c}\text { Postoperative } \\
\text { Complications }\end{array}$ & $\begin{array}{c}\text { Survival (months) } \\
\text { Cause of death or } \\
\text { Comments }\end{array}$ \\
\hline I & M & 52 & T4NIM0 & III & DG-DI & Pulmonary & - & 47,67 & $\begin{array}{c}\text { CHT - Alive with bone } \\
\text { recurrence }\end{array}$ \\
2 & F & 82 & T4NIM0 & III & DG-DI & - & - & Primary cancer \\
3 & M & 76 & - & IV & Repair & - & Pulmonary heart & $<1$ & Surgery-related \\
4 & F & 78 & T3NOMX & II & DG-DI & Cardiac & - & $<3$ & Surgery-related \\
5 & F & 73 & - & IV & Repair & - & Pulmonary embolism & $<1$ & Surgery-related \\
6 & M & 8 I & T2N0MX & I & DG-DI & - & Anastomotic Leakage & I8,80 & Primary cancer \\
7 & M & 57 & - & IV & Repair & - & - & $<1$ & Surgery-related \\
8 & F & 65 & - & IV & Repair & - & Bleeding & 5,20 & Primary cancer \\
9 & M & 66 & T2NIMX & II & DG-D2 & - & - & 41,60 & CHT - Alive \\
I0 & M & 50 & T3N2MX & III & TG-D3 & - & Bleeding & 25,60 & Primary cancer \\
\hline
\end{tabular}

DG, distal gastrectomy; TG, total gastrectomy; DI, D2, D3, lymph node dissection; CHT, adjuvant chemotherapy.

age of 65 years ( 68 years in our series) in contrast with the mean age of 51 years of the patients with perforated peptic ulcers [9-13]. Even during surgery the gastric ulcer is often diffucult to be characterized as benign or malignant by the surgeon. Therefore a biopsy and frozen section should be performed in all gastric perforations when a pathologist is available. Histologic determination is fundamental for the surgeon to choose the type of operation and to perform it with oncological criteria, for example considering adequate distance from the lesion and the resection margin. Malignant gastric perforation is more often a manifestation of advanced cancer with serosal invasion (55-82\%) and lymph node metastasis (57-67\%). Nevertheless, as confirmed by different observations $[14,15]$, gastric cancer can perforate at an early stage. Indeed at the pathologic examination of specimens, the process of gastric wall perforation is sustained by infectious and ischaemic factors due to the tumoral neovascularization which result in the shedding of the neoplastic tissue $[3,16]$.

It is still debated whether positive peritoneal cytology has an independent prognostic impact in gastric cancer. Several studies have noted free gastric cancer cells in the peritoneum to be associated with poor prognosis $[17,18]$. However, viable free cancer cells have not been demonstrated in the peritoneal cavity of patients with perforated gastric cancer and the metastatic efficiency of gastric cancer cells possibly shed during perforation is uncertain in the presence of the peritonitis; different studies, included the present one, report of long-term survivors[19]. When a curative operation can be performed, survival rates after gastric cancer perforation $[1,20]$ appear similar to survival rates observed in elective patients[21,22]. Moreover, Gertsch et al. demonstrated how the only factor predicting long term survival is the TNM stage, while age or the size, the location, the depth of infiltration and the histologic grading of the tumor or a delay in treatment after perforation showed no correlation with long-term survival[10].
Earlier, in 1997, Adachi et al. reviewed 155 cases of perforated gastric cancer collected from the Japanese literature finding that infiltrative gross type of the tumor, presence of serosal invasion, presence of lymph node metastasis, stage III-IV and curability of the tumor were the only negative prognostic factors influencing the 5 -years survival rate, while age, sex, location, histologic type and type of lymph node dissection were not found to be significantly related to the long term survival[1]. In another study of Gertsch et al., the Authors compared three groups of patients with perforated, bleeding and non-complicated gastric cancer, finding that perforation, as well as bleeding, does not significantly affect long term survival after gastrectomy[23].

Treatment of choice is still debated. Table 3 shows the results of our research in the International English literature. From the first study of Aird[24] in 1935 until the early 1980's we found how the most frequent type of operation performed for perforated gastric cancer was the simple closure or the omental patch, sometimes associated with gastroenteroanastomosis. In these papers is also shown the high surgery-related mortality of this type of surgery, nevertheless surgeons seemed to prefer simple repair, probably because malignant gastric perforation, with consequent peritoneal dissemination of tumor cells, was generally thought to be always a manifestation of terminal disease. Of course, the high mortality of simple closure is also due to the different kind of patients who undergo this type of minimal surgery: this approach is usually preferred for minimal therapy in frail patients or in advanced unresectable tumors. Therefore over the years the resection rate has been increasing and the overall mortality rate has been decreasing. In 2002 Lehnert et al.[9] proposed the two-stage radical gastrectomy as the treatment of choice in the majority of patients with perforated gastric cancer: this approach aims to avoid major surgical procedures in emergency performing a first-step simple 
Table 3: Published series of patients with perforated gastric cancer.

\begin{tabular}{|c|c|c|c|c|c|c|c|c|}
\hline \multirow[b]{2}{*}{ Reference } & \multirow[b]{2}{*}{$\mathrm{N}^{\circ}$ patients } & \multirow[b]{2}{*}{ Incidence (\%) } & \multirow[b]{2}{*}{$\begin{array}{l}\text { Preoperative } \\
\text { diagnosis (\%) }\end{array}$} & \multirow[b]{2}{*}{$\begin{array}{l}N^{\circ} \text { Repair } \\
\text { surgery }\end{array}$} & \multicolumn{3}{|c|}{ Mortality (\%) } & \multirow[b]{2}{*}{ Survival data } \\
\hline & & & & & $N^{\circ}$ Gastrectomy & Repair & Gastrectomy & \\
\hline Aird 1935[24]* & 38 & - & 7.5 & 31 & 7 & $22(7 I)$ & 0 & - \\
\hline McNealy 1938[4]* & 63 & 4.0 & 33.8 & 47 & 7 & $39(82)$ & $2(29)$ & - \\
\hline Casberg 1940[31] & 5 & 2.4 & 0 & 5 & 0 & $4(80)$ & - & - \\
\hline Bisgard 1945[5]* & 115 & $2.8-6.0$ & 3.2 & 80 & 15 & $59(74)$ & $2(13)$ & - \\
\hline Larmi 1962[13] & 19 & 3.0 & 42.1 & 16 & 4 & $8(50)$ & 0 & $\begin{array}{l}\text { Survival range in resected cases } \\
18-42 \text { months }\end{array}$ \\
\hline Wilson 1966[12] & 14 & 1.2 & 30.8 & 5 & 5 & 0 & 0 & $\begin{array}{l}\text { Survival range of patients with } R_{0} \\
\text { resection, } 15-41 \text { months; with } \\
R_{1}-R_{2} 4-15 \text { months }\end{array}$ \\
\hline Cortese 1972[II] & 13 & 0.6 & 40.0 & 11 & 2 & $3(27)$ & 0 & $\begin{array}{l}\text { Survival range of patients with } R_{0} \\
\text { resection, I4-108 months; with } \\
R_{1}-R_{2} 2 \text { months }\end{array}$ \\
\hline $\begin{array}{l}\text { Stechenberg } \\
1981[3]\end{array}$ & 9 & 3.9 & 0 & 7 & 2 & $2(29)$ & 0 & $\begin{array}{l}\text { Mean survival, } 5 \text { months (range } \\
\mid-18 \text { ) }\end{array}$ \\
\hline Siegert 1982[32] & 4 & 2.3 & 25 & 0 & 4 & - & 0 & Range of survival, $1-18$ months \\
\hline Miura 1985[20] & 9 & 0.6 & 33.3 & 1 & 8 & - & - & $\begin{array}{l}\text { Median survival, } 108 \text { months } \\
\text { (range, 4-144) }\end{array}$ \\
\hline Gertsch $1995[10]$ & 34 & - & 29.4 & 4 & 30 & $2(50)$ & $5(17)$ & $\begin{array}{l}\text { Median survival stage I } 50 \\
\text { months; III, I } 7 \text { months; IV } 4 \\
\text { months }\end{array}$ \\
\hline Adachi 1997[I]* & 155 & $0.5-3.6$ & 34.7 & 27 & 128 & $19(70)$ & $9(7)$ & $\begin{array}{l}\text { 5-years survival stage I-II, 76\%; } \\
\text { III-IV, I9\% }\end{array}$ \\
\hline Lehnert 2000[9] & 23 & 1.8 & 39.1 & $12^{\dagger}$ & 11 & $\mathrm{I}(8)$ & $2(18)$ & $\begin{array}{l}5 \text {-years survival } R_{0}, 50 \% ; 2 \text {-years } \\
\text { survival } R_{1}-R_{2}, 9 \%\end{array}$ \\
\hline Kasakura 2002[2] & 16 & 0.7 & 31.2 & $2 \ddagger$ & 14 & $\mathrm{I}(50)$ & $\mathrm{I}(7)$ & $\begin{array}{l}\text { Median survival stage I-II } 75 \\
\text { months; III-IV, } 4.8 \text { months }\end{array}$ \\
\hline Ozmen 2002[25] & 14 & 3.0 & 35.7 & $3 \S$ & $11 \ddagger$ & $\mathrm{I}(33)$ & $4(36)$ & - \\
\hline IRGGC 2005 & 10 & 0.4 & 30.0 & 4 & 6 & $3(75)$ & $\mathrm{I}(17)$ & See text and Table 2 \\
\hline
\end{tabular}

* Collected series; † 5 patients underwent secondary radical gastrectomy; $¥$ I patient underwent secondary radical gastrectomy; 2 patients underwent secondary radical gastrectomy.

closure or a gastric resection and later, a secondary elective gastrectomy with oncological radicality intent. This kind of approach has been approved by Ozmen et al.[25] who found that preoperative shock is a negative prognostic factor influencing surgery-related mortality.

\section{Conclusion}

From the the personal experience of the IRGGC and from the studies reported in the literature we tried to make the point for the treatment of choice of perforated gastric carcinoma. Perforated gastric carcinoma is not to be considered as a unique disease, but the surgeon should consider the single elements that compose every peculiar clinical case. The treatment of the peritonitis would require a minimal surgery in order to avoid major procedures in an emergency situation; on the other hand the treatment of gastric cancer would require an oncological-oriented surgery in order to satisfy oncological radicality criteria. These two aims are not always compatible in a single emergency surgical treatment. The most important factors to be recalled in the management of a patient with histological diagnosis of perforated gastric carcinoma are: 1 ) the presence of preoperative shock[26];2) the gravity of peritonitis; 3) the curability of the neoplasm; 4) eventual comorbidities of the patient. If we add together points 1 , 2 and 4 considering them as the general condition of the patient, we may identify four classes of patients with different options for surgical treatment (Figure 1). If a patient has a curable tumor and acceptable general condition, for example no signs of shock, localized peritonitis and no comorbidities, the treatment of choice seems to be radical total or subtotal gastrectomy with associated D2 or D3 lymphadenectomy or, for a less aggressive approach, twostage radical gastrectomy. When general condition is good but the tumor is at an advanced stage with no possibility of $\mathrm{R}_{0}$ resection, a palliative gastrectomy, if technically possible, is recommended considering the minor surgeryrelated mortality[27]. Two-stage radical gastrectomy seems to find its peculiar indication when general condition is poor but a curative resection is possible, even though this approach was never chosen in our experience. Simple repair or omental patch are reserved only for those patients with advanced stage disease and whose general condition is poor. If a pathologist is not available and histologic examination is not possible during surgery, we suggest to perform a gastric resection, since for perforated 


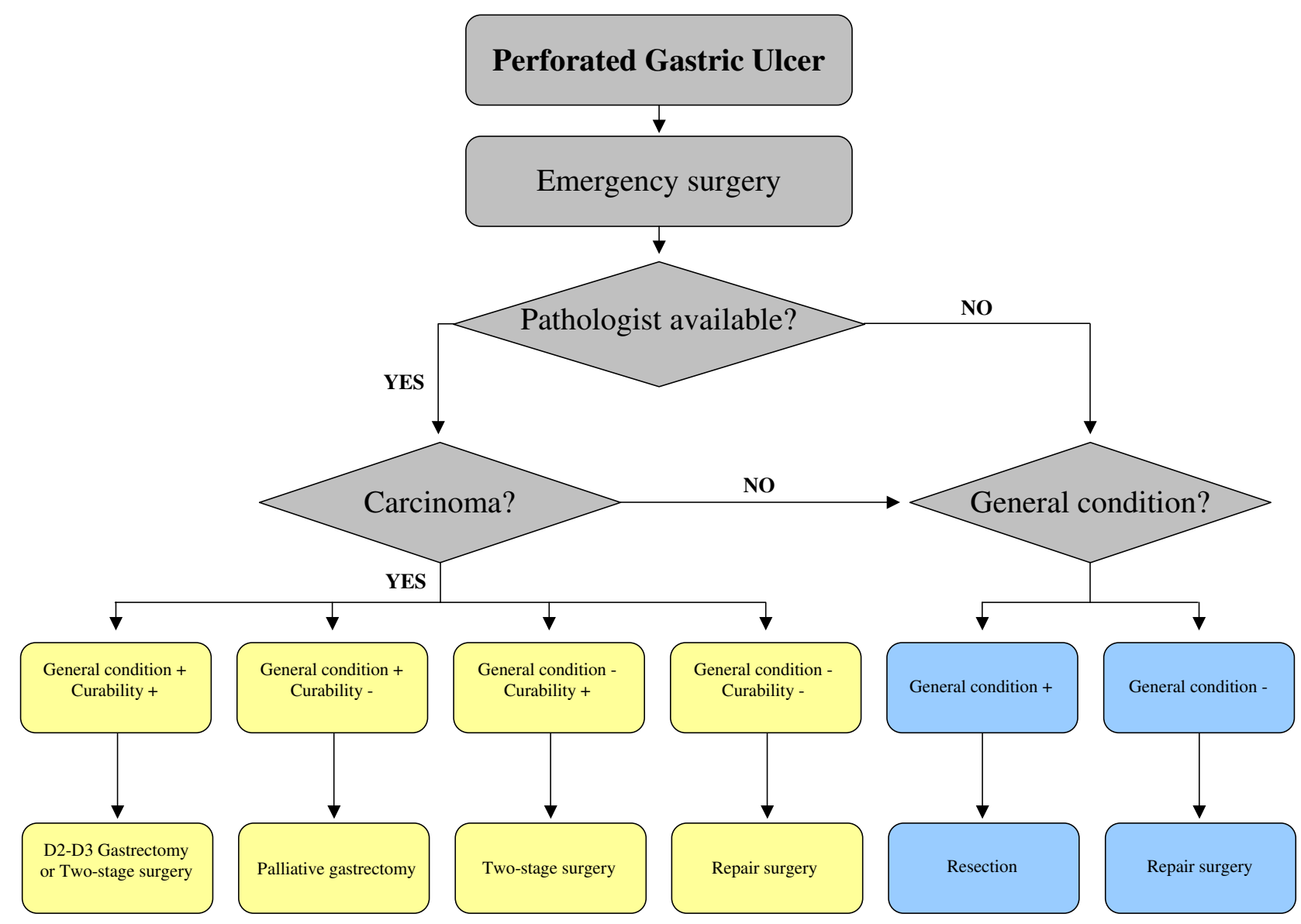

\section{Figure I}

Decisional flow-chart for perforated gastric cancer. General condition includes 3 factors: haemodynamics, gravity of peritonitis and comorbidities.

peptic ulcer too the treatment of choice is resection both for the better morbility and the lower rate of recurrence [28-30]; only intraoperative hemodynamic instability should limit operative selection to a faster procedure. In both cases when the postoperative histologic examination would assess the malignancy of the ulcer a secondary radical gastrectomy is mandatory.

\section{Competing interests}

The author(s) declare that they have no competing interests.

\section{Authors' contributions}

FR: conceived of the study and participated in the design of the study
SR: participated in the design of the study and drafted the manuscript

DM: participated in the design of the study and performed the statistical analysis

GDM: participated in the design of the study

CP: participated in the design of the study

PM: participated in the design of the study

GC: participated in the design of the study and helped to draft the manuscript

EP: coordinated the study 


\section{Acknowledgements}

None

\section{References}

I. Adachi Y, Mori M, Maehara Y, Matsumata T, Okudaira Y, Sugimachi $\mathrm{K}$ : Surgical results of perforated gastric carcinoma: an analysis of 155 Japanese patients. Am J Gastroenterol 1997, 92(3):516-8

2. Kasakura Y, Ajani JA, Fujii M, Mochizuki F, Takayama T: Management of perforated gastric carcinoma: a report of 16 cases and review of world literature. Am Surg 2002, 68:434-40.

3. Stechenberg $L$, Bunch RH, Anderson MC: The surgical therapy for perforated gastric cancer. Am Surg 1981, 47:208-2I0.

4. McNealy RW, Hedin RF: Perforation in gastric carcinoma. J Am Coll Surg 1938, 67:818-823.

5. Bisgard JD: Gastric resection for certain acute perforated lesions of stomach and duodenum with diffuse soiling of the peritoneal cavity. Surgery 1945, 17:498-509.

6. Sage M, Ghoutti A, Delalande JP, Alexandre JH, Champault G, Patel JC: Notre expérience clinique de dix cas de péritonite par perforation de cancer gastrique au cours de la dernière décenne. Ann Chir 1983, 37:355-359.

7. Kennedy TL: Gastric carcinoma and acute perforation. Brit Med J 195I, 2: I 489

8. Mouchet A, Marquand J: A propos de $\mathbf{2}$ cas de perforations en péritoine libre des néoplasmes gastriques. Arch Mal Appar Dig $1953,42: 634-645$

9. Lehnert T, Buhl K, Dueck M, Hinz U, Herfarth C: Two-stage radical gastrectomy for perforated gastric cancer. Eur J Surg Oncol 2000, 26:780-784

10. Gertsch P, Yip SKH, Chow LWC, Lauder IJ: Free perforation of gastric carcinoma. Results of surgical treatment. Arch Surg 1995, 130:177-181.

II. Cortese AF, Zahn D, Cornell GN: Perforation in gastric malignancy. I Surg Oncol 1972, 4:190-206.

12. Wilson TS: Free perforation in malignancies of the stomach. Can J Surg 1966, 9:357-364.

13. Larmi TKI: Perforation of gastric carcinoma. Acta Chir Scand 1962, I 23:222-227.

14. Andreoni B, Salvini P, Gridelli B, Balestri M, Strada L, Tognini L, Grezzi C, Bevilacqua G: Diagnostic précoce du cancer de l'estomac: 23 cas dont 15 avec complication aigue d'hémorragie ou de perforation. J Chir (Paris) I 98I, I I 8:253-259.

15. Kitakado Y, Tanigawa N, Muraoka R: A case report of perforated early gastric cancer. Nippon Geka Hokan 1997, 66:86-90.

16. Sarro Palau M, Sans Segarra M: Cirugia de urgencia en el cancer gastrico. Rev Esp Enf Ap Digest 1974, 42:529-536.

17. Bonenkamp JJ, Songun I, Hermans J, van de Velde CJ: Prognostic value of positive cytology findings from abdominal washing in patients with gastric cancer. BrJ Surg 1996, 83:672-674.

18. Wu CC, Chen JT, Chang MC, Ho WL, Chen CY, Yeh DC, Liu TJ, P'eng FK: Optimal surgical strategy for potentially curable serosa-involved gastric carcinoma with intraperitoneal cancer cells. J Am Coll Surg 1997, 184:6 I I-6I7.

19. Adachi Y, Aramaki M, Shiraishi N, Shimoda K, Yasuda K, Kitano S: Long-term survival after perforation of advanced gastric cancer: case report and review of the literature. Gastric Cancer 1998, I:80-83.

20. Miura T, Ishii T, Shimoyama T, Hirano T, Tomita M: Surgical treatment of perforated gastric cancer. Dig Surg 1985, 2:200-204

21. Cuschieri A, Weeden S, Fielding J, Bancewicz J, Craven J, Joypaul V, Sydes $M$, Fayers $P$ : Patient survival after $D 1$ and $D 2$ resections for gastric cancer: long term results of the UK MRC randomised surgical trial. Br J Cancer 1999, 79: I522-1530.

22. Bonenkamp |J, Hermans J, Sasako M, van de Velde C): Extended lymph-node dissection for gastric cancer. N Engl J Med I999, 340:908-914.

23. Gertsch P, Choe LWC, Yuen ST, Chau KY, Lauder If: Long term survival after gastrectomy for advanced bleeding or perforated gastric carcinoma. Eur J Surg 1996, 162:723-727.

24. Aird I: Perforation of carcinoma of the stomach into the general peritoneal cavity. Br J Surg 1935, 22:545-554.

25. Ozmen MM, Zulfikaroglu B, Kece C, Aslar AK, Ozalp N, Koc M: Factors influencing mortality in spontaneous gastric tumour perforations. J Int Med Res 2002, 30:180-184.
26. So JBY, Yam A, Cheah WK, Kum CK, Goh PM: Risk factors related to operative mortality and morbidity in patients undergoing emergency gastrectomy. Br J Surg 2000, 87: 1702-1707.

27. Kasakura Y, Ajani JA, Mochizuki F, Morishita Y, Fujii M, Takayama T: Outcomes after emergency surgery for gastric perforation or severe bleeding in patients with gastric cancer. J Surg Oncol 2002, 80: $|8|-185$.

28. McGee GS, Sawyers JL: Perforated gastric ulcers. A plea for management by primary gastric resection. Arch Surg 1987, | 22:555-56 |.

29. Tsugawa K, Koyanagi N, Hashizume M, Tomikawa M, Akahoshi K, Ayukawa K, Wada H, Tanoue K, Sugimachi K: The therapeutic strategies in performing emergency surgery for gastroduodenal ulcer perforation in 130 patients over 70 years of age. Hepatogastroenterology 200I, 48:I56-162.

30. Vibert E, Boufflerd C, Régimbeau JM, Menegaux F: Ulcère gastrique perforé: suture ou gastrectomie? Ann Chir 2005, I30:92-95.

3I. Casberg MA: Perforation as complication of gastric carcinoma. Arch Surg 1940, 41 :937-944.

32. Siegert TA, Donegan WL: Acute perforation of gastric carcinoma. Wis Med J 1982, 8 I: I7-21.
Publish with Bio Med Central and every scientist can read your work free of charge

"BioMed Central will be the most significant development for disseminating the results of biomedical research in our lifetime. "

Sir Paul Nurse, Cancer Research UK

Your research papers will be:

- available free of charge to the entire biomedical community

- peer reviewed and published immediately upon acceptance

- cited in PubMed and archived on PubMed Central

- yours - you keep the copyright

Submit your manuscript here:

http://www.biomedcentral.com/info/publishing_adv.asp
BioMedcentral 